\title{
ON THE REGULATION OF THE BLOOD VOLUME IN NORMAL AND NEPHRITIC ANIMALS. ${ }^{+}$
}

\author{
By А. Е. Вочсотт. \\ From the Pathological Departments of Guy's Hospital, London, S.E., and the \\ University, Manchester.
}

\section{PART I.-EXPERIMENTS WITH SALT SOLUTIONS.}

URANIUM nitrate administered in suitable doses to rabbits causes necrosis of the cells of the convoluted tubules of the kidneys. ${ }^{2}$ After a short time the secretion of urine fails and the animal dies. About 2 mgrms. per kilo of body weight, given by subcutaneous injection, is the smallest dose which produces this effect; lesser quantities cause transient albuminuria, which generally ends in recovery. With doses of 10 mgrms. per kilo suppression of urine supervenes on the second or third day, and most of the rabbits die on the fourth to sixth days. There is no definite change of weight one way or the other, and the animals eat fairly well and show no very obvious signs of general illness up to about the last day of life. ${ }^{3}$ After death the kidneys show complete or approximately complete necrosis of the convoluted tubules; in some cases this extends to the epithelium of the ascending limb of Henle's loop; the glomeruli remain quite normal in appearance. No other organs show pathological changes, except that occasionally two or three inches of the large intestine appears to be somewhat inflamed; diarrhœa occurs in a small proportion of cases. On post-mortem examination there is no obvious oedema; determinations of the water content by drying to constant weight at $100^{\circ} \mathrm{C}$. show no excess of water in the heart or skeletal muscles; the kidneys can, however, by this means, be shown to be abnormally watery as soon as twenty-four hours after the administration of uranium and

${ }^{1}$ Received April 23, 1913.

2 For the literature of uranium nephritis, see T. Suzuki, "Zur Morphologie der Nierensekretion" (Jena, Fischer, 1912), and the list given in this Journal, 1913, vol. xvii, p. 458.

${ }^{3}$ They appear, however, to be abnormally susceptible to cold, and should be kept in an atmosphere a good deal warmer than is suitable for healthy rablits if premature deaths are to be avoided. 
before the secretion of urine has in any way failed. Obvious and more or less generalised œdema may, however, be produced by giving extra water either by the stomach tube or by injection. A similar result is said not to be obtained in cases where the tubular epithelium has been destroyed by chromium salts, so that there is some reason for thinking that uranium has some special action on the capillary walls or some other part of the mechanism which regulates the distribution of water in the body. ${ }^{1}$

This œedema, which may be brought about in nephritic animals by the administration of water, involves the blood as well as the rest of the tissues. In the experiments shown in Tables I. and II. sterilised Ringer's solution was injected daily into the peritoneal cavity, and observations were made on the concentration of hæmoglobin in the blood. The quantity injected was 48 c.c. per kilo (i.e., the blood volume) in the case of rabbits $A$ and $B$, and 24 c.c. per kilo of the normal body weight in the case of rabbits $C$ and $D$. Injections were made on the days marked ${ }^{*}$.

TABLE I.-Normal Rabbits.

\begin{tabular}{|c|c|c|c|c|c|c|c|c|c|}
\hline \multirow{2}{*}{ Day. } & \multicolumn{4}{|c|}{$\begin{array}{l}\text { Percentage of Hæmoglobin on the } \\
\text { Human Scale. }\end{array}$} & \multirow{2}{*}{ Day. } & \multicolumn{4}{|c|}{$\begin{array}{l}\text { Percentage of Hæmoglobin on the } \\
\text { Human Scale. }\end{array}$} \\
\hline & A & B & $\mathrm{C}$ & $\mathrm{D}$ & & A & B & $\mathrm{C}$ & $\mathrm{D}$ \\
\hline 1 & 74 & 72 & 77 & 81 & $8^{*}$ & 79 & 82 & 80 & 82 \\
\hline $2^{*}$ & 70 & 78 & 78 & 82 & $9^{*}$ & 73 & 77 & 74 & 85 \\
\hline $3^{*}$ & 73 & 72 & 74 & 81 & $10^{*}$ & 73 & 79 & 78 & 84 \\
\hline $4^{*}$ & 70 & 75 & 78 & 79 & $11 *$ & 69 & 80 & 74 & 85 \\
\hline $5^{*}$ & 66 & 75 & 79 & 79 & 12 & 70 & 78 & 76 & 90 \\
\hline
\end{tabular}

These results show that the introduction into the body of normal rabbits, over a period of ten days, of volumes of salt solution up to a third of their body weight, does not lead to any hydræmia.

With nephritic animals, on the other hand, a definite blood dilution is easily produced (Table II.); this is associated with more or less excess of fluid in the pleural and peritoneal cavities, and with a less ${ }^{\circ}$ obvious cedema of the loose connective tissue in general.

\footnotetext{
1 According to Suzuki, uranium acts on the second and third parts of the proximal convoluted tubule, and especially on the third part, whereas chromium destroys the first part and to some extent the second. My own observations with uranium, however, lead me to conclude that the localisation depends to a large extent on the dose ; with small doses (e.g., 2 mgrms. per kilo) parts of the convoluted tubules appear to escape, but it is easy enough to destroy the whole of the epithelium with larger quantities.
} 
TABLE II.-Nephritic Rabbits.

(10 mgrms. uranium nitrate per kilo on the third day.)

\begin{tabular}{|c|c|c|c|c|c|c|c|c|c|}
\hline \multirow{2}{*}{ Day. } & \multicolumn{4}{|c|}{$\begin{array}{l}\text { Percentage of Hæmoglobin on the } \\
\text { Human Scale. }\end{array}$} & \multirow{2}{*}{ Day. } & \multicolumn{4}{|c|}{$\begin{array}{c}\text { Percentage of Hæmoglobin on the } \\
\text { Human Scale. }\end{array}$} \\
\hline & A & B & $\mathrm{C}$ & $\mathrm{D}$ & & A & B & $\mathrm{C}$ & $\mathrm{D}$ \\
\hline 1 & 71 & 84 & 79 & 75 & $6^{*}$ & 50 & 67 & 80 & 61 \\
\hline 2 & 72 & 84 & 79 & 74 & $7^{*}$ & 49 & 56 & 64 & 55 \\
\hline 3 & 68 & 78 & $7 \vec{i}$ & 71 & $8^{*}$ & 50 & 60 & 61 & 56 \\
\hline $5^{*}$ & 64 & 82 & 78 & 72 & 9 & (Dead) & $\begin{array}{c}53 \\
\text { (Died) }\end{array}$ & $\begin{array}{c}52 \\
\text { (Killed) }\end{array}$ & (Dead) \\
\hline
\end{tabular}

These facts are sufficient to show that the distribution of water in the body is disarranged by the induction of acute uranium nephritis, not, it is true, in the sense that any obvious rearrangement of the water already present occurs, but by way of a failure to make provision for the disposal of any excess of liquid which may be brought into account. The failure to maintain the proper volume of the blood is perhaps particularly striking, since in normal animals this is kept practically constant, under wide variation of water intake, partly by the kidneys and partly by the storage of water in the extravascular tissues.

Salt solution, for example, when injected intravenously, is partly excreted by the kidneys and partly stored in the tissues. ${ }^{1}$ In a series of experiments made by J. H. Ryffel and myself, Ringer's solution in quantity equal to balf or the whole blood volume of the recipient animal was quickly injected intravenously into normal rabbits. The urine was collected during the following half hour, at the end of which time the blood volume would be restored to normal, and all the injected liquid would have passed out of the circulation. In eighteen such experiments on ten animals 1357 c.c. was injected altogether, and 348.9 c.e. of urine obtained; in other words, just about three-quarters of the injected Ringer left the circulation and accumulated in the tissues, while only one quarter was immediately excreted by the kidneys. In two cases the urine obtained amounted to more than half the volume injected, and in three others to more than one-third.

The object of the present experiments has been to ascertain whether any definite experimental evidence could be obtained that this failure to regulate the volume of the blood is due to an alteration in the permeability of the capillary wall, and I have sought to do this by measuring the rates at which liquids of various kinds will pass to and fro between the tissues and the blood in normal and nephritic 
animals. The present communication deals chiefly with the passage of salt solutions from the blood to the tissues.

\section{METhOD OF ExPERIMENT.}

Rabbits were used in all cases. The nephritic animals received a uniform dose of 10 mgrms. uranium nitrate per kilo, given subcutaneously in 1 per cent. watery solution; they were used for experiment on the fourth or fifth day after, that is about one and a half to three days after they had ceased to secrete urine, and on the latest day on which there was a prospect of a fair proportion of them being still alive. Anæsthesia was obtained with ether and urethane, 1.5 to 1.6 grms. per kilo being given subcutaneously. Injections were made into the jugular vein, and samples of blood obtained from the carotid artery. The kidneys were thrown out of action in the normal animals by tying the ureters close to the bladder; only 2 or 3 c.c. of urine are secreted under the circumstances, and the somewhat severe interference of tying the renal vessels is avoided. For the sake of uniformity the ureters were also tied in the anuric nephritic animals. Care was taken in all cases to maintain the animal's temperature; a gas-heated copper tank, fitted with a Hearson regulator, was found very satisfactory for this purpose.

The general scheme of the experiments was much the same as that adopted by Leathes. ${ }^{1}$ Having ascertained the concentration of hæmoglobin in the blood by means of a standard Gowers-Haldane hæmoglobinometer, a known quantity of liquid, equal to the calculated blood volume, was then injected into the circulation. At regular intervals thereafter the concentration was measured, and from these figures the relative blood volume could readily be ascertained. The protocol of an actual experiment is as follows:-

4th December.-RABBiT, Female (2720 grms.).

\begin{tabular}{|c|c|c|c|c|c|c|c|}
\hline Time. & $\begin{array}{l}\text { Hæmoglobin } \\
\text { per cent. }\end{array}$ & $\begin{array}{c}\text { Relative } \\
\text { Blood } \\
\text { Volume. }\end{array}$ & $\begin{array}{c}\text { Absolute } \\
\text { Blood } \\
\text { Volume. }\end{array}$ & Time. & $\begin{array}{l}\text { Hæmoglobin } \\
\text { per eent. }\end{array}$ & $\begin{array}{c}\text { Relative } \\
\text { Blood } \\
\text { Volume. }\end{array}$ & $\begin{array}{l}\text { Absolute } \\
\text { Blood } \\
\text { Volume. }\end{array}$ \\
\hline $\begin{array}{l}10.45 \\
10.50 \\
10.55 \\
11.0 \\
11.5\end{array}$ & $\begin{array}{c}68 \\
68 \\
\text { 130 c.c. Ringer's } \\
\text { solution in- } \\
\text { jected in- } \\
\text { trayenously } \\
\text { during fiye } \\
\text { minutes } \\
\\
51 \\
55 \\
63 \\
67 \\
69\end{array}$ & $\begin{array}{r}132 \\
123 \\
107 \\
101 \\
98\end{array}$ & $\begin{array}{l}172 \\
160 \\
140 \\
132 \\
128\end{array}$ & $\begin{array}{l}11.10 \\
11.15 \\
11.20 \\
11.25 \\
11.30 \\
11.35 \\
11.40 \\
\\
11.45 \\
11.50 \\
11.55 \\
12.0 \\
12.5\end{array}$ & $\begin{array}{c}130 \text { c.c. Ringer's } \\
\text { solution in } \\
\text { jected as before } \\
51 \\
58 \\
65 \\
68 \\
70 \\
\text { 130 c.c. Ringer's } \\
\text { solution in- } \\
\text { jected as before } \\
55 \\
58 \\
67 \\
68 \\
69\end{array}$ & $\begin{array}{r}131 \\
115 \\
103 \\
98 \\
95 \\
\ldots\end{array}$ & $\begin{array}{c}171 \\
150 \\
134 \\
128 \\
124 \\
\ldots\end{array}$ \\
\hline
\end{tabular}

${ }^{1}$ Journ. Physial., London, 1895-96, vol. xix. p. 1. 
For the purpose of calculating the blood volume $I$ have assumed that the average rabbit of 2 to 3 kilos has 48 c.c. of blood per kilo of body weight. In this case, therefore, the assumed volume is $\frac{2720}{1000} \times 48=130$ c.c. The injections of Ringer's fluid ${ }^{1}$ or other liquid were all made on a uniform plan by which the whole blood volume could be injected in five minutes, 5 per cent. of the blood volume (in this case 6.5 c.c.) being passed in every fifteen seconds. If the whole of the injected liquid had still been in the circulation at the end of the injection period, the volume of the blood would have been doubled and the hæmoglobin percentage would have fallen from 68 to 34 per cent. Immediately on the completion of the injection, however, the hæmoglobin was found to be 51 per cent., giving a relative blood volume of $100 \times \frac{68}{51}=133$ instead of 200 , and an absolute volume of 173 c.c. instead of 260 c.c. Evidently, therefore, 87 c.c., or 67 per cent. of the liquid injected, had passed out of the vessels before the injection was finished. During the next five minutes the hæmoglobin rose to 55 per cent, indicating a relative volume of 124 and an absolute volume of 161 c.c., and the passage of 12 c.c. from the blood to the tissues. In the same way 20 c.c. and 8 c.c. left the blood in the two following five-minute periods, accounting for the disappearance during twenty minutes of 127 c.c. out of the 130 c.c. injected. During the fifth period the volume was restored to the normal level. The procedure was then repeated twice with very much the same result.

It will be noticed that the calculation of the relative blood volume, directly from the percentages of hæmoglobin observed before and after injecting, is to some extent vitiated by the removal of blood in taking the samples. Before taking each sample the dead end formed by the clamped carotid has to be washed out with a drop or two of blood, as it is most essential that the sample taken for examination should be fairly representative of the circulating blood. These various drops of blood may, however, be readily collected, and the amount of hæmoglobin lost in this way ascertained colorimetrically by titration against known hæmoglobin solutions. Adding to this the amounts used in the estimations, one can make an approximate correction of the observed figures. This has been done throughout this paper as regards the figures for "relative blood volume." Thus, in the example given above, the crude figures give relative volumes at 11.35 and 12.5 of 97 and 99 respectively, while the corrected figures are 95 and 96 . The error of the crude figures is in any case small, and there is some uncertainty about the correction; though absolute accuracy is not obtained, the corrected are certainly nearer the truth than the crude results.

Just what happens during the period of injection is not clear, and probably cannot be accurately ascertained by direct observation owing to the difficulty of securing a valid sample of the whole blood. Presumably, however, the quantity leaving the vessels is proportionate to the excess quantity which is already there; hence the volume

${ }^{1}$ Containing 0.9 per cent. $\mathrm{NaCl}, 0.042$ per cent. $\mathrm{KCl}, 0.024$ per cent. $\mathrm{CaCl}_{2}$, and 0.030 per cent. $\mathrm{Na}_{2} \mathrm{CO}_{3}$. 
increases quickly at first, and more slowly towards the end of the injection. This hypothesis corresponds with the view that the injection is, as it were, pushed out of the vessels, presumably in connection with the increased venous pressure which is occasioned by it. The alternative hypothesis is that the chief force which removes the injected liquid is a pulling force exerted by the tissue fluids. On this hypothesis, if 66 per cent. of the injection leaves the circulation in five minutes, 6.6 per cent. would leave during each halfminute, in which one-tenth of the whole quantity enters the vessels. At this rate, at the end of two and a half minutes, the relative blood volume would be 117 , on the first hypothesis something greater. I have seven experiments in which one-tenth of the calculated blood volume was injected each half minute for five periods (i.e., half the blood volume in all), and the relative volume ascertained at the end of a further two and a half minutes (i.e., five minutes from the commencement of the injection). The volumes found then were 112, 113, $118,119,119,122$, and 131 , on an average 119 , a result which is obviously incompatible with the "pulling" hypothesis. But it does not follow that the "pushing" idea in its simple form is necessarily correct.

It should be recognised that the accuracy of the figures given for the absolute blood volume depends on bow near one gets to the truth in assuming that the animal's normal blood volume is 48 c.c. per kilo. ${ }^{1}$ While this is perhaps as likely a figure as any other, it is probable that among the whole series of rabbits the value varied up to about 15 per cent. on either side of this average figure. On the other hand, the figures for relative blood volume are independent of any such assumption, and are based solely on the observed hæmoglobinometer readings. The calculated rate of disappearance of liquid from the circulation is, however, dependent on the calculated blood volume, since it is based on the assumption that all the animals were treated in exactly the same way as regards the quantity of fluid injected and the relative rate of injection. It is no doubt actually true that some animals received, relatively to their blood volumes, more than others, though this difference should be largely obliterated by averaging the results. In each case the same amount relative to the body weight was given, and great care was taken that all the experiments should be done in just the same way, so that they should be fully comparable with one another in all points under experimental control.

\section{A.-Experiments with Ringer's Solution $(0.9$ per cent. $\mathrm{NaCl})$.}

1. Normal animals.-Of ten experiments, in one the animal received two injections, each equal in bulk to its calculated blood

1 This Journal, 1912, vol. xvi. p. 485. 
volume, in two experiments three injections were made, and in one experiment four injections; in the remaining six experiments only one dose was given. Dealing first with the simplest case, we have the following data, showing the rate at which a first injection leaves the vessels. The figures indicate the relative blood volume at intervals of five minutes, the first period being occupied with the injection.

TABLE III.-Normal Animals; first Injections.

\begin{tabular}{|c|c|c|c|c|c|c|c|c|c|}
\hline \multirow{3}{*}{ No. } & & \multirow{3}{*}{$\begin{array}{l}\text { Sex and } \\
\text { Weight. }\end{array}$} & \multirow{3}{*}{$\begin{array}{c}\text { Hæmoglobin } \\
\text { Percentage } \\
\text { before Injection. }\end{array}$} & \multicolumn{6}{|c|}{ Relative Blood Volume after } \\
\hline & & & & \multicolumn{6}{|c|}{ Minutes. } \\
\hline & & & & 0 & 5 & 10 & 15 & 20 & 25 \\
\hline $\begin{array}{r}\text { II. } \\
\text { IV. } \\
\text { XIII. } \\
\text { XIX. } \\
\text { XX. } \\
\text { XLIII. } \\
\text { XLVI. } \\
\text { XLVII. : } \\
\text { XLIX. } \\
\text { LII. : }\end{array}$ & : & $\begin{array}{l}\text { M., } 2000 \\
\text { M., } 1920 \\
\text { F., } 2250 \\
\text { F., } 3100 \\
\text { M., } 2200 \\
\text { F., } 2070 \\
\text { F., } 2200 \\
\text { M.', } 1920 \\
\text { F., } 2720 \\
\text { M., } 2040\end{array}$ & $\begin{array}{l}71 \cdot 3 \\
63 \cdot 7 \\
73 \\
76 \\
75 \\
99 \\
74 \cdot 5 \\
75 \\
68 \\
69\end{array}$ & $\begin{array}{l}100 \\
100 \\
100 \\
100 \\
100 \\
100 \\
100 \\
100 \\
100 \\
100\end{array}$ & $\begin{array}{l}136 \\
140 \\
139 \\
135 \\
138 \\
135 \\
132 \\
131 \\
132 \\
118\end{array}$ & $\begin{array}{l}110 \\
124 \\
113 \\
120 \\
113 \\
110 \\
113 \\
108 \\
123 \\
110\end{array}$ & $\begin{array}{r}102 \\
111 \\
108 \\
106 \\
103 \\
106 \\
105 \\
99 \\
107 \\
102\end{array}$ & $\begin{array}{r}98 \\
105 \\
103 \\
103 \\
105 \\
103 \\
104 \\
97 \\
101 \\
101\end{array}$ & $\begin{array}{r}99 \\
103 \\
102 \\
103 \\
102 \\
100 \\
103 \\
94 \\
98 \\
99\end{array}$ \\
\hline \multicolumn{3}{|c|}{ Average relative volume } & - & 100 & $133 \cdot 6$ & $114: 4$ & $104: 9$ & $102 \cdot 0$ & $100 \cdot 3$ \\
\hline \multicolumn{4}{|c|}{ Average per cent. of injection lost } & $\ldots$ & $66 \cdot 4$ & $19 \cdot 2$ & $9 \cdot 5$ & $2 \cdot 9$ & $1 \cdot 7$ \\
\hline
\end{tabular}

On the average, therefore, just about two-thirds of the injected liquid was found to have left the circulation by the time the injection was finished; 19 per cent. goes during the next five minutes, 9.5 per cent. during the next, 3 per cent. in the next period, and after twenty-five minutes from the beginning of the injection the blood volume has been restored to normal. In the first period, therefore, 66 per cent. of what has been put in leaves the vessels, and in the next three periods 57 per cent., 66 per cent., and 59 per cent. respectively of the excess present at the beginning of the period.

As regards the quantity lost during the period of the injection, most of the experiments are in close agreement. In the first nine the calculated amount varied only between 60 and 69 per cent. Assuming that the actual loss in each case was 66.4 per cent. of the injection, these variations would entail that rabbits IV. and xuvir. had 40 and 52 c.c. of blood per kilo respectively, figures quite within the range of probability. On the same assumption, however, rabbit LII., in which 82 per cent. disappeared, had a calculated normal blood volume of 90 c.c. per kilo, a result which indicates that in this particular case the process took a materially different course.

2-JL. OF PATH.-VOL. XVIII. 
TABLE IV.-Normal Animals; second Injections.

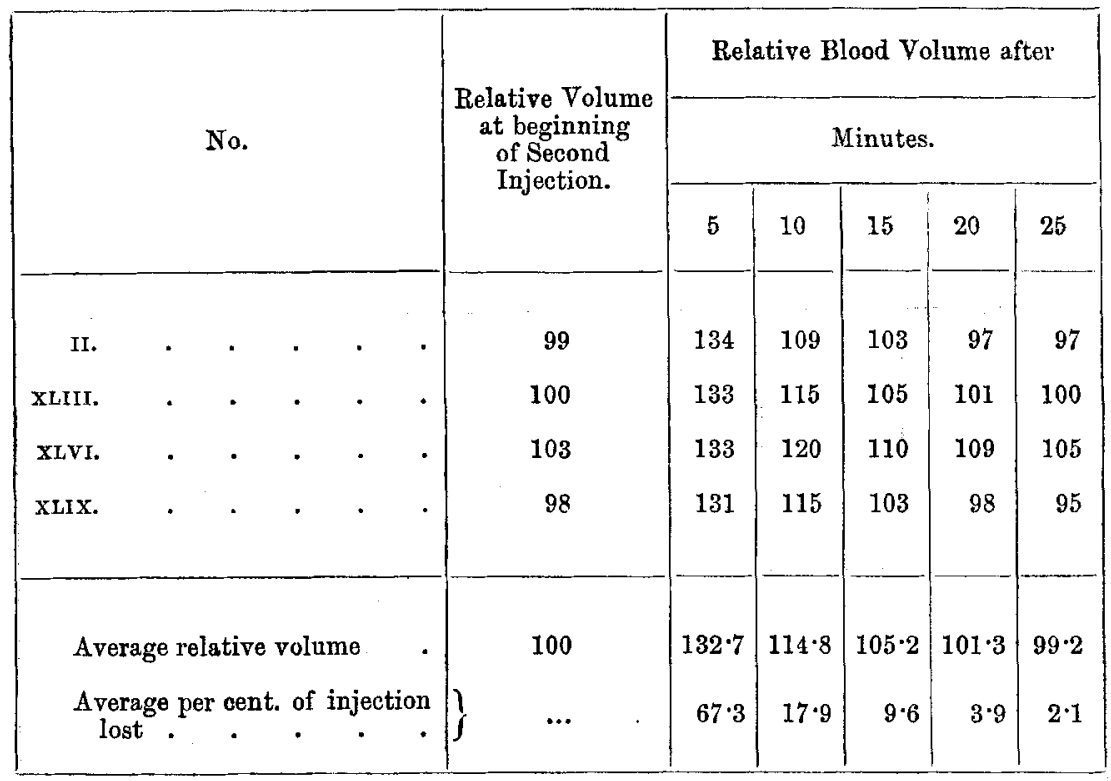

TABLE V.-Normal Animals; third Injections.

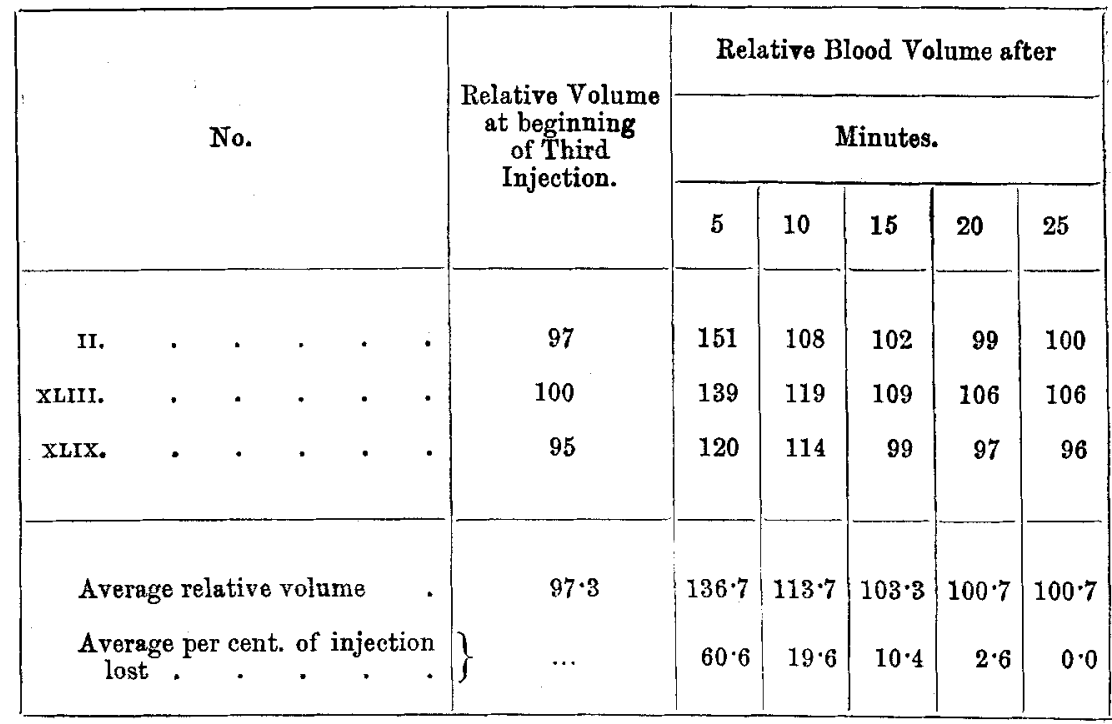

With second and third injections much the same result is obtained. There is, indeed, no appreciable difference in the average figures of the three series of experiments, and it is somewhat remarkable that an animal can so easily dispose of a volume of salt solution equal to 
three times its normal quantum of blood. ${ }^{1}$ The data are shown graphically in Fig. 1: in this, and in Fig. 2, the curves are drawn

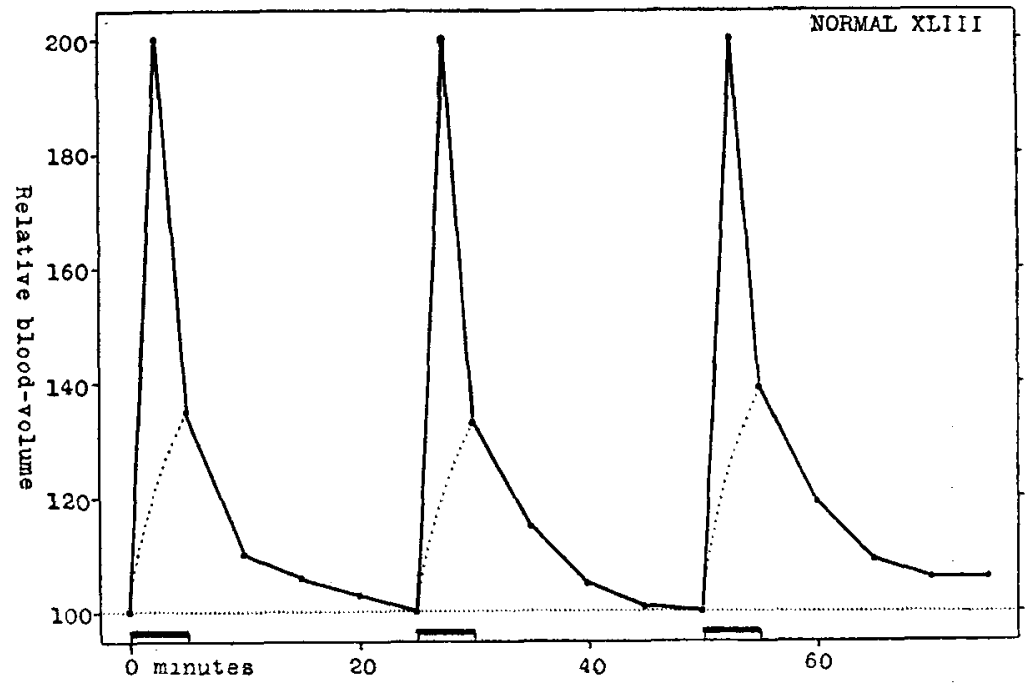

FIG. 1.

as if the whole injection was in the circulation at the same time and the blood volume actually doubled. This, of course, is not actually

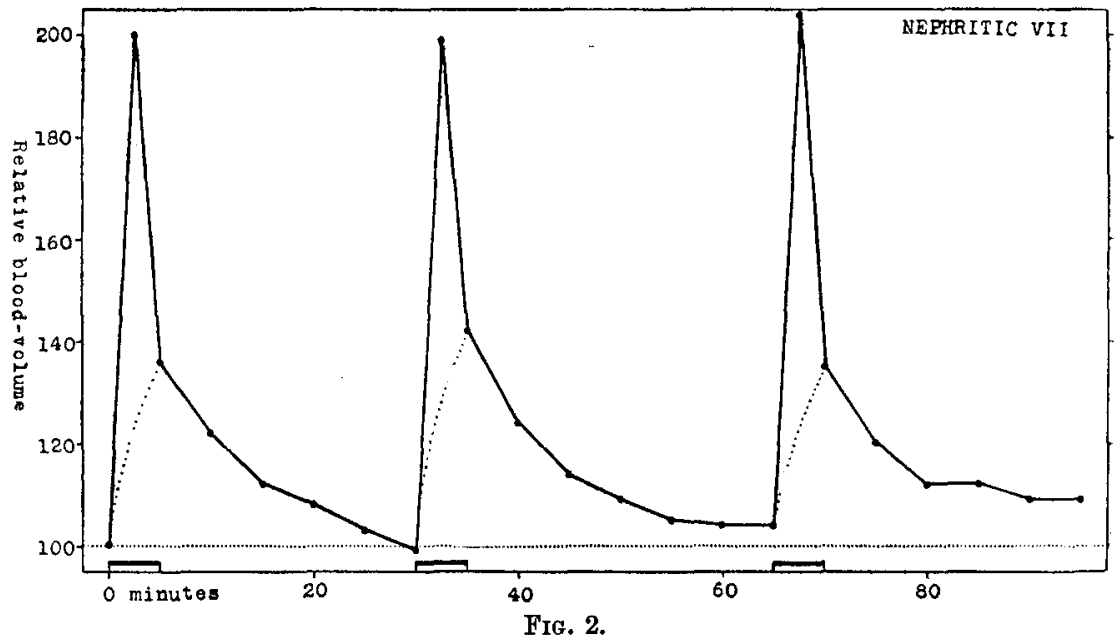

the case; the more probable course of events is shown by the dotted lines. In the single animal, which received a fourth injection, only

${ }^{1}$ On killing these animals one finds no general cedema. There may be a little fluid (10 c.c. Ca) in the pleural or peritoneal cavities, or in both, and there is the same marked renal and perirenal odema that is generally seen after several doses of any diuretic : the contents of the alimentary canal also appear rather more watery than usual. The kidneys are out of action, and there is no discharge of liquid from the bowel. The excretion of water from the respiratory apparatus would not account for more than 2 or 3 c.c. per hour. 
41 per cent. disappeared during the first five minutes; but 82 per cent. had gone in ten and 95 per cent. in fifteen minutes, so that the result was not very different from those of earlier injections in its main features.

2. Nephritic animals.-In the corresponding series of nephritic animals, which were treated in all respects in as exact parallel with the normal animals as possible, one had three injections, four two injections, and four only one dose.

TABLE VI.-Nephritic Animals ; first Injections.

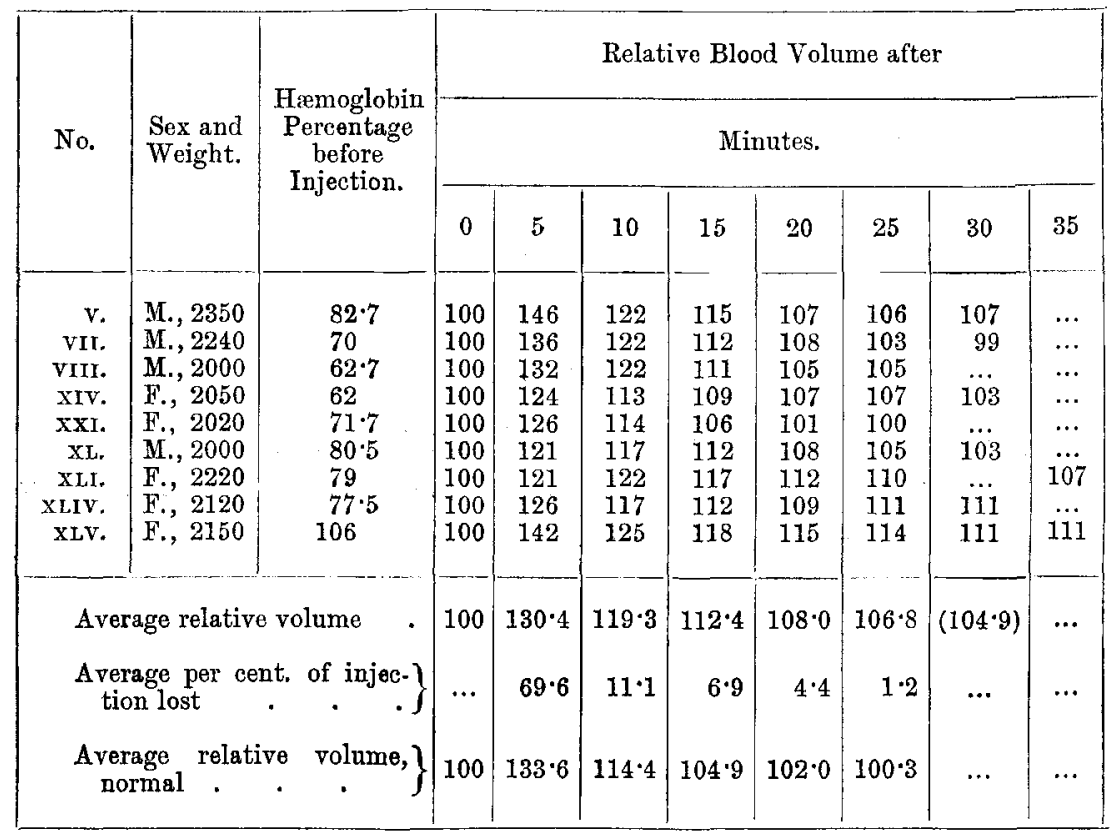

As with the normal animals, the greater part of the injection (in this case 70 per cent.) leaves the vessels during the period of injection; thereafter the rate becomes slower, and in the three succeeding periods only 37,36 , and 35 per cent. of the excess present at the beginning of each period finds its way to the tissues. In the result the blood volume is restored more slowly and less completely.

The results, especially as regards the loss during the period of injection, are obviously more variable than in the normal series. We notice especially a number of animals (XL., XLI., XIV., XXI., and XLIV.) in which the rate of disappearance during this period was faster than in any of the normal animals, though after ten and especially after fifteen minutes their blood volume was further from its proper level, i.e., the loss during the second and third periods was much slower than in the normal series. One possible interpretation of this phenomenon might obviously be sought in a variability and abnor- 
mality of the blood volume before injection. For example, rabbit XL. got rid of 79 per cent. of the injected liquid in the first five minutes as compared with rabbit $v$., which ejected from the circulation in the same time only 54 per cent. Be it assumed that both of them actually got rid of the average amount $(69.6$ per cent.), and that the variation is due to an error in calculating that the volume of the injection was in both cases equal to the blood volume, the truth being that it was more in the case of rabbit $v$. and less in the case of rabbit XL. The injection in each case being actually 48 c.c. per kilo, it follows that rabbit v. has only 42 c.c. blood per kilo and rabbit xL. as much as 53 c.c., - both within the normal range of variation. It is unnecessary, therefore, to suppose that there was anything abnormal in the blood volume before injection, and indeed that there is any abnormal variability in the results obtained.

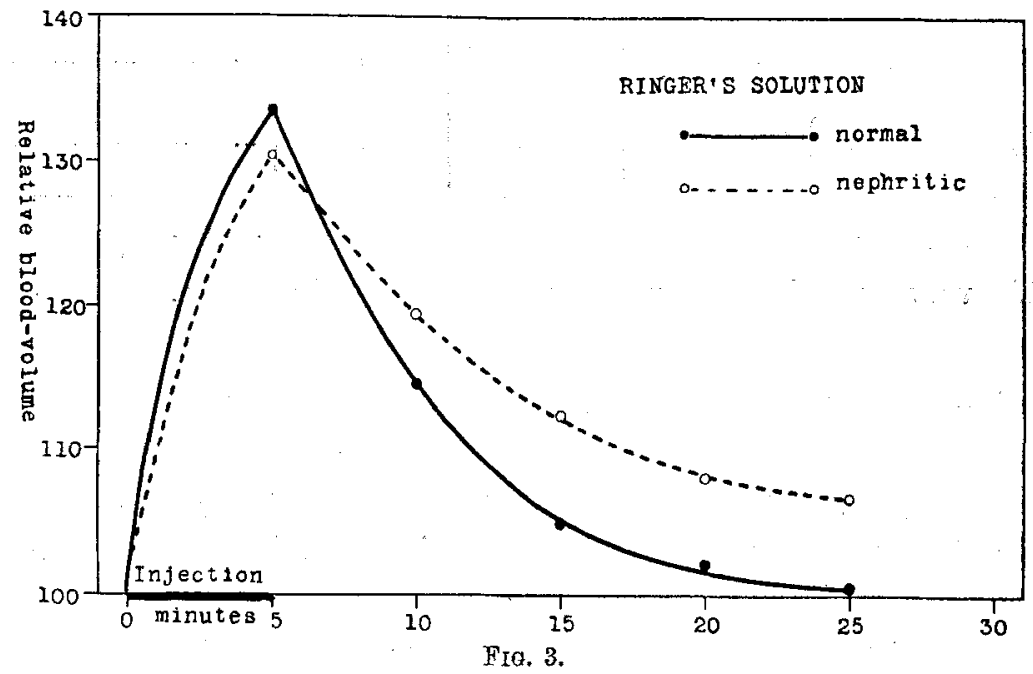

In this series, as in the others, one cannot make out any definite correlation between the rate of volume-restoration and the concentration of hæmoglobin before injection. In extreme cases the relation between the volumes of plasma and injection varies a good deal. Thus an animal with a hæmoglobin percentage of 106 has about 25 c.c. plasma per kilo, one with 62 per cent. of hæmoglobin 35 c.c. plasma, and an average rabbit with 78 per cent. 31 c.c. plasma. These differences are, of course, exaggerated if the deviations from the average concentration are due to deviation from the average total volume. ${ }^{1}$ There is some suggestion in the data that rabbits with a high hæmoglobin percentage lose the injected liquid more slowly than those with dilute blood, but there is no definite evidence of a real difference. Such as it is, it is readily explicable on the hypothesis that high concentration is associated with small volume.

${ }^{1}$ See this Journal, 1912, vol. xvi. p. 494. 
TABLE VII.-Nephritic Animals; second and third Injections.

\begin{tabular}{|c|c|c|c|c|c|c|c|c|c|c|c|c|}
\hline \multirow{3}{*}{$\begin{array}{l}\text { No. of } \\
\text { Rabbit. }\end{array}$} & \multirow{3}{*}{ 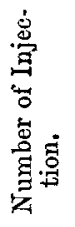 } & \multirow{3}{*}{ 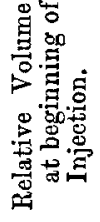 } & \multicolumn{10}{|c|}{ Relative Blood Volume after } \\
\hline & & & \multicolumn{10}{|c|}{ Minutes. } \\
\hline & & & 5 & 10 & 15 & 20 & 25 & 30 & 35 & 40 & 45 & 55 \\
\hline VIr. - & 2 & 99 & 142 & 124 & 114 & 109 & 105 & 104 & 104 & $\ldots$ & & \\
\hline XLI. . & 2 & 103 & 123 & 123 & 116 & 112 & 111 & $\ldots$ & 110 & $\ldots$ & 111 & 113 \\
\hline xLIV. . & 2 & 111 & 127 & 119 & 114 & 111 & 111 & $\ldots$ & 111 & $\cdots$ & $\ldots$ & \\
\hline XLV. . & 2 & 111 & 157 & 137 & 127 & 123 & 122 & . & $\ldots$ & 119 & $\ldots$ & 121 \\
\hline VII. . & 3 & 104 & 135 & 120 & 112 & 112 & 109 & 109 & $\ldots$ & $\ldots$ & $\ldots$ & $\cdots$ \\
\hline $\begin{array}{l}\text { Average } \\
\text { volume }\end{array}$ & lative & $f^{105 \cdot 6}$ & $136 \cdot 8$ & $124 \cdot 6$ & $116 \cdot 6$ & $113 \cdot 4$ & $111 \cdot 6$ & $\cdots$ & $\cdots$ & $\cdots$ & $\cdots$ & $\cdots$ \\
\hline $\begin{array}{l}\text { Average pe } \\
\text { of inject }\end{array}$ & $\begin{array}{l}\text { cent. } \\
\text { n lost }\end{array}$ & \}$\ldots$ & $68 \cdot 8$ & $12 \cdot 2$ & $8 \cdot 0$ & $3 \cdot 2$ & 1.8 & $\cdots$ & $\cdots$ & $\cdots$ & $\cdots$ & $\cdots$ \\
\hline $\begin{array}{l}\text { Average } \\
\text { volume, }\end{array}$ & $\begin{array}{l}\text { ative } \\
\text { rmal }\end{array}$ & 99 & $134 \cdot 4$ & $114 \cdot 3$ & $104^{*} 4$ & $101 \cdot 0$ & $99^{\cdot} \cdot 9$ & $\cdots$ & $\cdots$ & $\cdots$ & $\cdots$ & $\cdots$ \\
\hline
\end{tabular}

Here again the disposal of second and third injections does not differ very much in its course from that of first injections.

\section{B.-Experiments with Ringer's Solution of Half Strength $(0.45$ per cent. $\mathrm{NaCl})$.}

1. Normal animals were used in two experiments, in each of which the animal received three successive injections of 48 c.c. per kilo.

TABLE VIII.-Half-strength Ringer; Normal Animals.

\begin{tabular}{|c|c|c|c|c|c|c|c|c|c|c|}
\hline \multirow{3}{*}{$\begin{array}{c}\text { No. of } \\
\text { Animal. }\end{array}$} & & \multirow{3}{*}{$\begin{array}{l}\text { Sex and } \\
\text { Weight. }\end{array}$} & \multirow{3}{*}{ 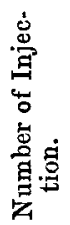 } & \multirow{3}{*}{ 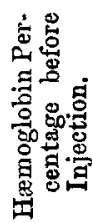 } & \multicolumn{6}{|c|}{ Relative Blood Volume after } \\
\hline & & & & & \multicolumn{6}{|c|}{ Minutes. } \\
\hline & & & & & 0 & 5 & 10 & 15 & 20 & 25 \\
\hline XVII. & - & $\begin{array}{l}\text { F., } 2260 \\
\text { F., } 2000\end{array}$ & $\left\{\begin{array}{l}1 \\
2 \\
3 \\
1 \\
2 \\
3\end{array}\right.$ & $\begin{array}{c}69 \\
\ldots \\
\ldots \\
\ldots \\
70 \\
\ldots .\end{array}$ & $\begin{array}{l}100 \\
102 \\
100 \\
100 \\
101 \\
101\end{array}$ & $\begin{array}{l}118 \\
128 \\
124 \\
116 \\
115 \\
112\end{array}$ & $\begin{array}{l}114 \\
119 \\
116 \\
114 \\
111 \\
112\end{array}$ & $\begin{array}{l}104 \\
107 \\
110 \\
105 \\
105 \\
106\end{array}$ & $\begin{array}{l}102 \\
103 \\
103 \\
101 \\
101 \\
101\end{array}$ & $\begin{array}{l}102 \\
100 \\
101 \\
101 \\
101 \\
100\end{array}$ \\
\hline \multicolumn{4}{|c|}{ Average relative volume } & . & $100^{\prime} 7$ & $118 \cdot 8$ & $114 \cdot 3$ & $106 \cdot 2$ & $101 \cdot 8$ & $100 \cdot 8$ \\
\hline \multicolumn{5}{|c|}{ Average per cent. of injection lost } & $\ldots$ & $81 \cdot 9$ & $4 \cdot 5$ & $8 \cdot 1$ & $4 \cdot 4$ & $1 \cdot 0$ \\
\hline
\end{tabular}


As much, therefore, as 82 per cent. of the injected fluid leaves the vessels during the period of injection. The subsequent loss is at a slower rate, ${ }^{1}$ but in twenty-five minutes the normal volume is restored. In one case second and third injections disappeared rather more slowly; in the other animal rather faster than the first doses. In view of the correspondence in the experiments with normal Ringer, it is perhaps justifiable to average all the results.

2. Nephritic animals. - The two corresponding experiments on nephritic animals gave the following results :-

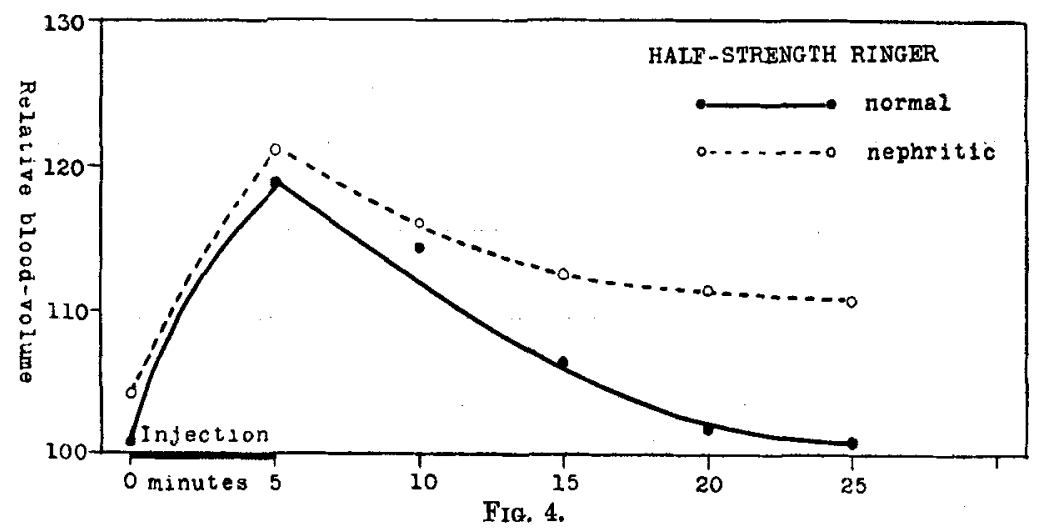

TABLE IX.-Half-strength Ringer; Nephritic Animals.

\begin{tabular}{|c|c|c|c|c|c|c|c|c|c|c|c|c|}
\hline \multirow{3}{*}{$\begin{array}{l}\text { No. of } \\
\text { Animal. }\end{array}$} & \multirow{3}{*}{$\begin{array}{l}\text { Sex and } \\
\text { Weight. }\end{array}$} & \multirow{3}{*}{ 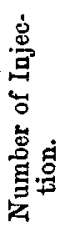 } & \multirow{3}{*}{ 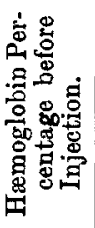 } & \multicolumn{9}{|c|}{ Relative Blood Volume after } \\
\hline & & & & \multicolumn{9}{|c|}{ Minutes. } \\
\hline & & & & 0 & 5 & 10 & 15 & 20 & 25 & 30 & 35 & 40 \\
\hline xxxix. & $\begin{array}{l}\text { M., } 1980 \\
\text { M. , } 2070\end{array}$ & $\left\{\begin{array}{l}1 \\
2 \\
3 \\
1 \\
2\end{array}\right.$ & $\begin{array}{l}81 \\
\cdots \\
\ldots \\
64 \\
\cdots\end{array}$ & $\begin{array}{l}100 \\
106 \\
110 \\
100 \\
104\end{array}$ & $\begin{array}{l}118 \\
122 \\
131 \\
111 \\
123\end{array}$ & $\begin{array}{l}109 \\
121 \\
125 \\
106 \\
119\end{array}$ & $\begin{array}{l}107 \\
115 \\
119 \\
104 \\
116\end{array}$ & $\begin{array}{l}109 \\
113 \\
119 \\
104 \\
112\end{array}$ & $\begin{array}{l}106 \\
112 \\
119 \\
104 \\
112\end{array}$ & $\begin{array}{l}\cdots \\
\cdots \\
\cdots \\
\cdots \\
110\end{array}$ & $\begin{array}{l}110 \\
\cdots \\
\cdots \\
\cdots\end{array}$ & $\begin{array}{c}117 \\
\ldots \\
\ldots\end{array}$ \\
\hline \multirow{3}{*}{\multicolumn{4}{|c|}{$\begin{array}{l}\text { Average relative volume } \\
\text { Average per cent. of injection lost } \\
\text { Average relative volume, normal }\end{array}$}} & $104 \cdot 0$ & $121 \cdot 0$ & $116 \cdot 0$ & $112 \cdot 5$ & $111 \cdot 4$ & $110 \cdot 6$ & ... & $\ldots$ & $\ldots$ \\
\hline & & & & $\cdots$ & $83 \cdot 0$ & $5 \cdot 0$ & $3 \cdot 5$ & $1 \cdot 1$ & 0.8 & $\ldots$ & $\ldots$ & $\cdots$ \\
\hline & & & & 100.7 & $118 \cdot 8$ & $114 \cdot 3$ & 106.2 & $101 \cdot 8$ & $100 \cdot 8$ & $\ldots$ & $\ldots$ & $\ldots$ \\
\hline
\end{tabular}

As with normal Ringer's solution, the readjustment of the blood volume is delayed in the nephritic animals.

1 The reading 114 at the end of second period seems to be irregular, and perhaps too high. Only 24 per cent. of the excess present at the beginning disappeared during the second period, as against 57 per cent. and 71 per cent. in the succeeding periods. The anomaly is not represented in the corresponding nephritic animals (Table IX.), but without further inquiry its significance, and indeed existence, must be regarded as doubtful. 


\section{C.-Experiments with Ringer's Solution of Double Strength (1.8 per cent. $\mathrm{NaCl})$.}

1. Normal animals.-Ringer's solution of double strength is less well borne than normal or half-strength solution; most of the animals in the end show signs of pulmonary oedema, and a fair proportion die from this cause. The two animals of which the details are given in Table $X$. showed no signs of failure of the circulation during the period covered by the figures.

TABLE X.-Double-strength Ringer; Normal Animals.

\begin{tabular}{|c|c|c|c|c|c|c|c|c|c|c|c|}
\hline \multirow{3}{*}{ 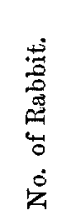 } & \multirow{3}{*}{ 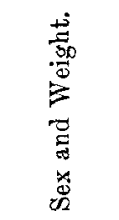 } & \multirow{3}{*}{ 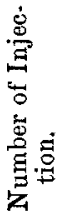 } & \multirow{3}{*}{ 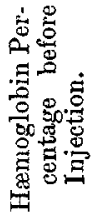 } & \multicolumn{8}{|c|}{ Relative Blood Volume after } \\
\hline & & & & \multicolumn{8}{|c|}{ Minutes. } \\
\hline & & & & 0 & 5 & 10 & 15 & 20 & 25 & 30 & 35 \\
\hline \multirow{2}{*}{ XVI. } & \multirow{3}{*}{ F., 2070} & $\int 1$ & 79 & 100 & 163 & 128 & 110 & 106 & 103 & 100 & $\cdots$ \\
\hline & & $(2$ & $\cdots$ & 100 & 165 & 131 & 119 & 115 & 108 & 104 & 102 \\
\hline \multirow{3}{*}{ xvirI. } & & $\int^{1}$ & 82 & 100 & 162 & 126 & 119 & 114 & 111 & 111 & 109 \\
\hline & \multirow[t]{2}{*}{ M., 2100} & 2 & $\cdots$ & 109 & 173 & 129 & 112 & 108 & 106 & 106 & 106 \\
\hline & & $(3$ & $\cdots$ & 106 & 168 & 127 & 111 & 108 & 109 & $\cdots$ & $\cdots$ \\
\hline \multirow{2}{*}{\multicolumn{4}{|c|}{$\begin{array}{l}\text { Average relative volume . } \\
\text { Average per cent. of injection lost }\end{array}$}} & $103 \cdot 0$ & $166^{\circ} 2$ & $128 \cdot 2$ & $114 \cdot 2$ & $110 \cdot 2$ & $107^{\circ} 4$ & $(105 \cdot 6)$ & $(104 \cdot 8)$ \\
\hline & & & & " & $36 \cdot 8$ & $38 \cdot 0$ & $14 \cdot 0$ & $4 \cdot 0$ & $2 \cdot 8$ & $\cdots$ & $\cdots$ \\
\hline
\end{tabular}

On the average, therefore, only about a third of the injection disappeared during the first five minutes. A little more than this was lost in the next five minutes, differing in this respect from the results with normal and half-strength Ringer. In the second to fifth periods respectively, 57 per cent., 50 per cent., 28 per cent., and 27 per cent. of the excess present at the beginning of each period left the circulation.

2. Nephritic animals. - The corresponding experiments on nephritic animals gave results which fail to show the delay characteristic of normal and half-strength Ringer. On the contrary, the rate is on the whole faster in the nephritic animals, and the general form of the curve more nearly resembles that of normal Ringer's solution. In the second to fifth periods respectively 50 per cent., 44 per cent., 52 per cent., and 32 per cent. of the excess at the beginning of each period is got rid of. 


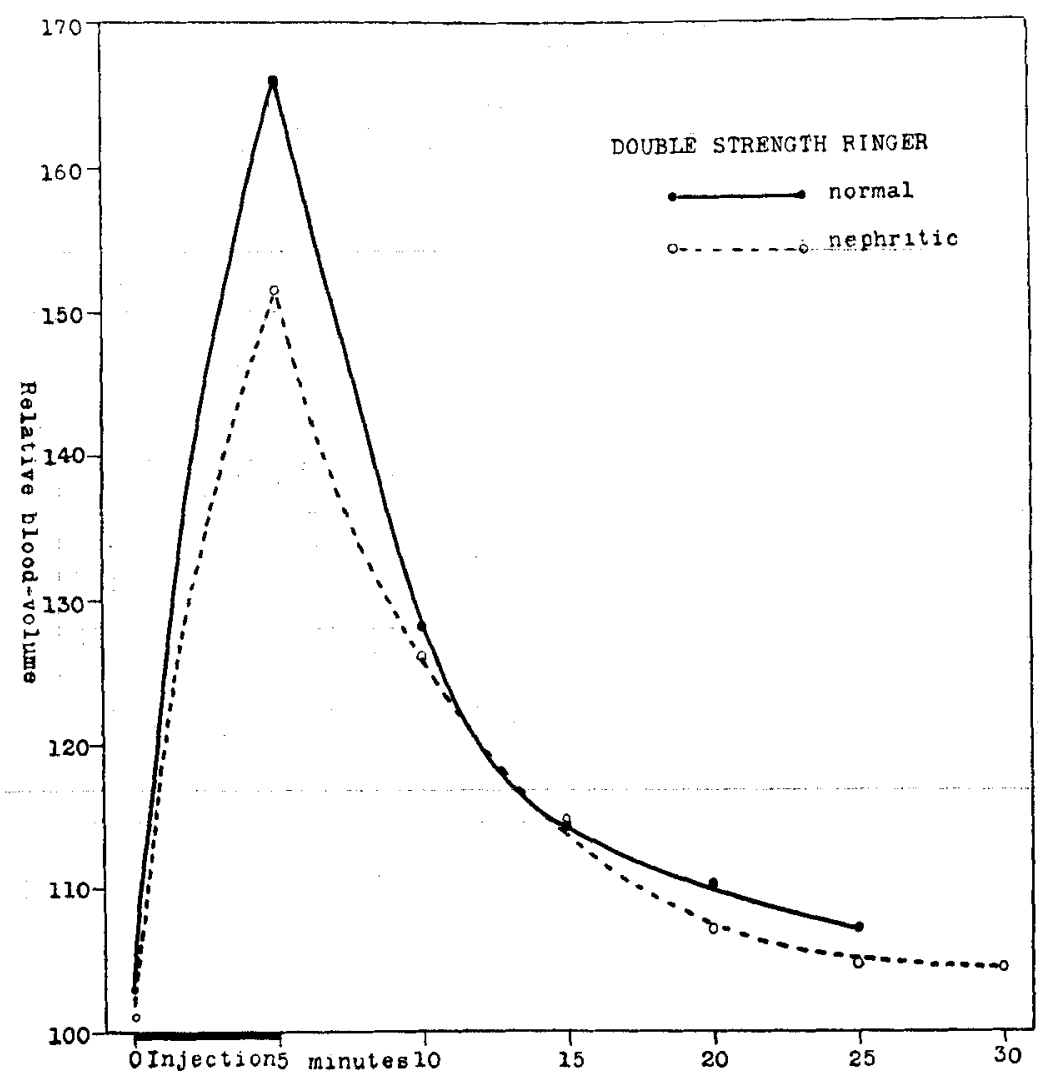

Fic. 5.

TABLE XI.-Double-strength Ringer; Nephritic Animals.

\begin{tabular}{|c|c|c|c|c|c|c|c|c|c|c|c|c|}
\hline \multirow{3}{*}{$\begin{array}{l}\text { No. of } \\
\text { Rabbit. }\end{array}$} & \multirow{3}{*}{$\begin{array}{c}\text { Sex } \\
\text { and } \\
\text { Weight. }\end{array}$} & \multirow{3}{*}{ 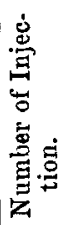 } & \multirow{3}{*}{ 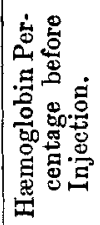 } & \multicolumn{9}{|c|}{ Relative Blood Volume after } \\
\hline & & & & \multicolumn{9}{|c|}{ Minutes. } \\
\hline & & & & 0 & 5 & 10 & 15 & 20 & 25 & 30 & 35 & 40 \\
\hline \multirow{4}{*}{$\begin{array}{l}\text { XXXIII. } \\
\text { XXXVIII. }\end{array}$} & \multirow{3}{*}{ F., 2720} & 1 & 83 & 100 & 172 & 131 & 116 & 111 & 107 & 105 & 102 & 102 \\
\hline & & 2 & $\ldots$ & 102 & 159 & 133 & 114 & 105 & 103 & 103 & 102 & $\ldots$ \\
\hline & & $\int 1$ & $65 \cdot 5$ & 100 & 144 & 116 & 112 & 104 & 103 & 102 & $\ldots$ & $\ldots$ \\
\hline & $x, 2000$ & 2 & $\cdots$ & 102 & 132 & 124 & 116 & 108 & 106 & 108 & $\ldots$ & $\cdots$ \\
\hline \multicolumn{4}{|c|}{ Average relative volume. } & $101 \cdot 0$ & $151 \cdot 7$ & $126 \cdot 0$ & $114 \cdot 5$ & $107 \cdot 0$ & $104 \cdot 8$ & $104 \cdot 2$ & $\ldots$ & $\ldots$ \\
\hline \multicolumn{4}{|c|}{ Average per cent. of injection lost } & $\ldots$ & $49 \cdot 3$ & $25 \cdot 7$ & $11 \cdot 5$ & $7 \cdot 5$ & $2 \cdot 2$ & 0.6 & $\ldots$ & $\ldots$ \\
\hline \multicolumn{4}{|c|}{ Average relative volume, normal } & 103.0 & 166.2 & $128 \cdot 2$ & $114^{\circ}$ & $110 \cdot 2$ & $107 \cdot 4$ & $\ldots$ & $\ldots$ & $\ldots$ \\
\hline
\end{tabular}




\section{Discussion of Results.}

Putting all these results together, we obtain the figures summarised in Table XII. Premising that the results should not necessarily

TABle XII.

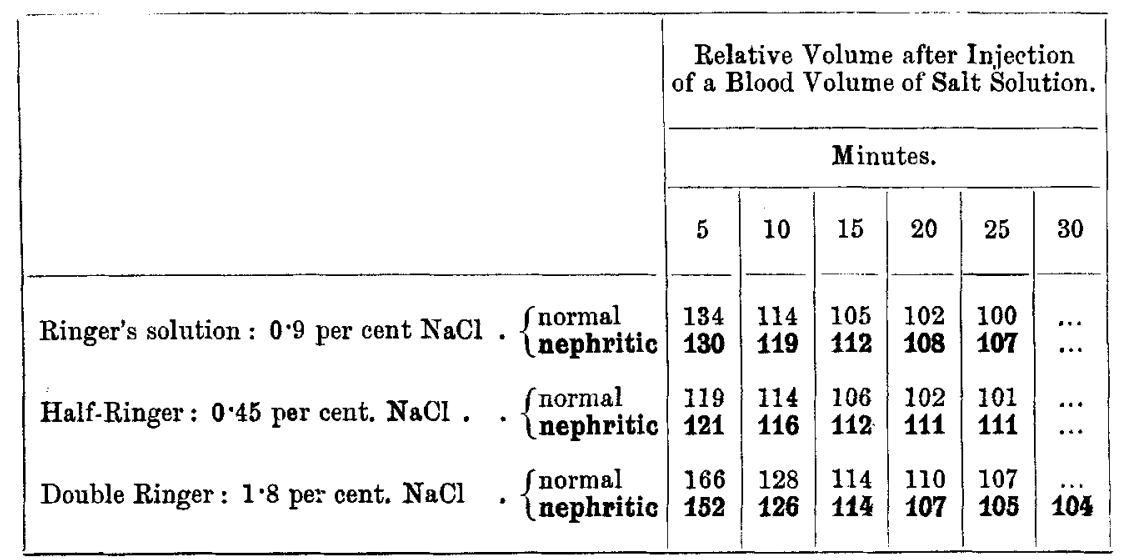

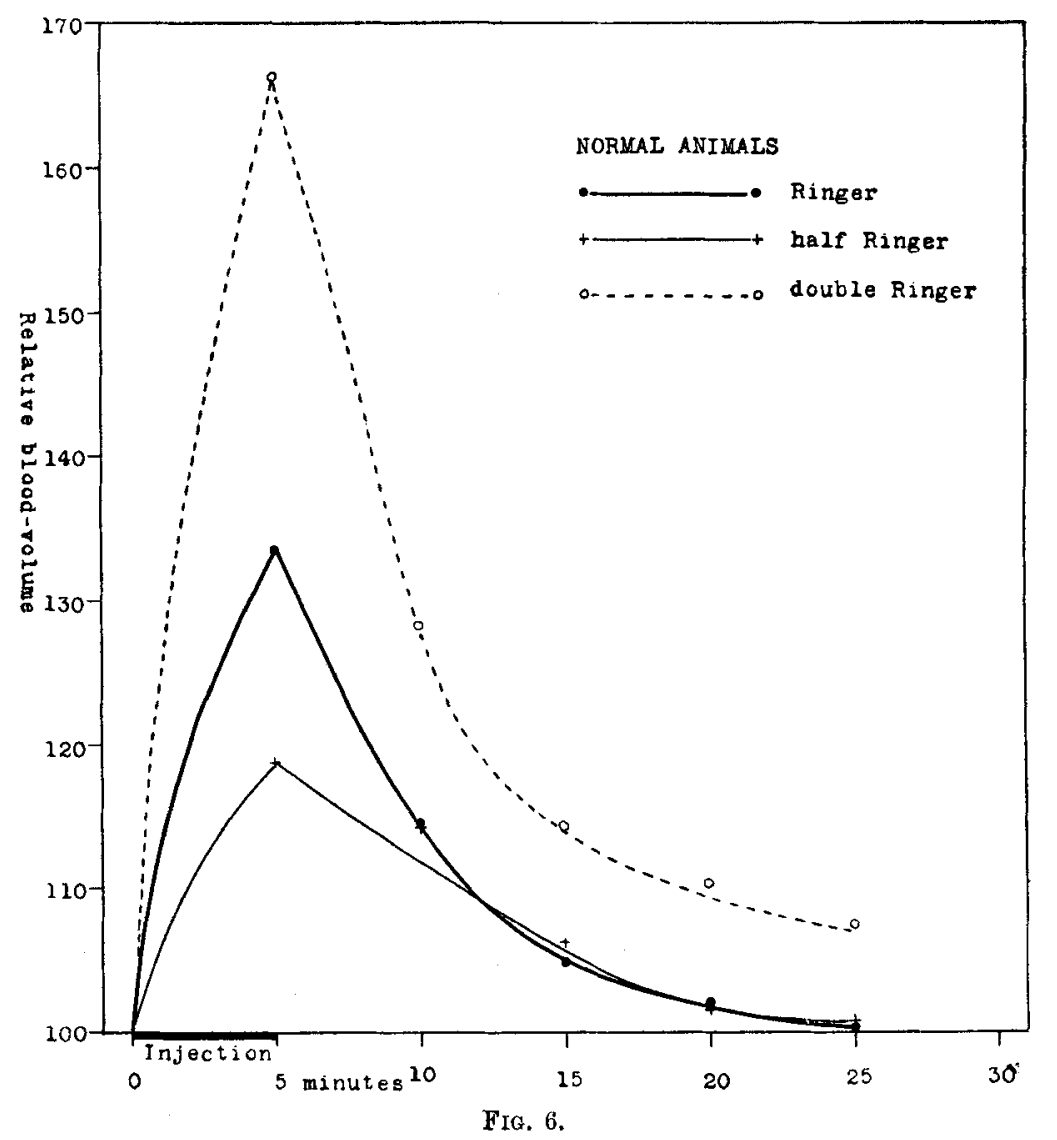


be considered applicable to any but the precise mode of procedure and rate of injection which was adopted in this series of experiments, we may conclude that

1. In normal animals Ringer's solution containing 0.9 per cent. $\mathrm{NaCl}$ leaves the blood and passes into the tissues more rapidly than a solution containing 1.8 per cent. $\mathrm{NaCl}$, and less rapidly than one with only $0.45 \mathrm{per}$ cent. $\mathrm{NaCl}$. The difference is particularly marked during the period of injection: with the normal solution 66 per cent. has left the blood by the time the injection is finished, with weak solution as much as 82 per cent., and with strong solution only 37 per cent. These differences (see Fig. 6) are presumably to be attributed to the tissue juices being more or less isotonic with 0.9 per cent., more concentrated than 0.45 per cent., and less concentrated than 1.8 per cent. In addition, therefore, to any other factors which may be operative, osmotic forces would actively suck liquid out of the blood with weak solution, while with the more concentrated mixtures there would be a tendency for tissue juice to pass into the vessels.

2. Ringer's solution containing 0.9 per cent. $\mathrm{NaCl}$ leaves the blood more rapidly in normal than in nephritic animals (see Fig. 3).

3. Ringer's solution containing 0.45 per cent. $\mathrm{NaCl}$ also passes out more quickly in normal animals (see Fig. 4).

4. Ringer's solution containing 1.8 per cent. $\mathrm{NaCl}$, on the other hand, leaves the blood rather faster in nephritic animals (see Fig. 5).

The factors which appear to be of importance in determining the adjustment of the volume of the blood under the conditions prevailing in these experiments are, firstly, the mechanical conditions inside the blood vessels, especially the rise of venous pressure ${ }^{1}$ secondly, the permeability of the capillary walls; and, thirdly, the molecular concentration of the extravascular tissue juice. As to the first factor I have no direct observations, but, in so far as the point is capable of really precise experimental investigation, there seems to be no reason for thinking that the conditions in the nephritic animals would be found to be materially different from those which prevailed in the normal controls. The third factor is also one which seems to be beyond the reach of experiment $;^{2}$ tissue juice cannot be obtained, and to apply the results of analyses of such fluids as lymph or peritoneal liquid to the present question is altogether beside the point.

1 The facts may be conveniently found in E. H. Starling "The Fluids of the Body" (London, 1909); see also C. Tigerstedt, Skandin. Arch. f. Physiol., Leipzig, 1908, Bd. xx. S. 197 , and 1909 , Bd. xxii. S. 157 .

${ }^{2}$ I have endeavoured to get information by injecting different solutions in succession, but the results are quite inconelusive. Normal Ringer's solution seems to accelerate the disappearance of both strong and dilute Ringer, but the previous injection of strong Ringer does not appear to quicken the disappearance of dilute Ringer and an injection of dilute Ringer has no clear influence on the rate of disappearance of strong Ringer, injected immediately afterwards. 
There is, moreover, no simple hypothesis with regard to the concentration of tissue juice which will explain the observed facts. One would naturally expect, on the whole, that the concentration would rise in anuric animals; this would be compatible with the data as regards strong ( 1.8 per cent.) Ringer, but the slower exit of normal $(0.9$ per cent.) and weak $(0.45$ per cent.) Ringer requires the assumption of an abnormally dilute tissue juice. In the same way, an alteration in the salt concentration in the blood ${ }^{1}$ affords no satisfactory explanation of the phenomena. One reaches, therefore, the provisional conclusion that experimental uranium nephritis decreases the permeability of the vessel wall in both directions. The slower passage of normal and weak salt solutions indicates that this applies to the paths leading from within outwards. The faster passage of concentrated salt solution is compatible with the hypothesis that the paths from without inwards are also obstructed. It is pretty clear that in normal animals the volume of the blood after the injection of 1.8 per cent. salt is the sum of the water and salt which are passing outwards, and of the water which is being sucked from the tissues into the blood. If the latter quantity is diminished, the result may well be that the injected liquid on the whole gets out of the vessels somewhat quicker in the nephritic animals.

With the idea of obtaining further information with regard to the passage of liquid from the tissues to the blood, experiments were also made on the restoration of the blood volume after hæmorrhages of about one-third. They proved unsatisfactory, because under the conditions of operation and anæsthesia which were used a loss of blood of this order generally led to the death of the animal about twenty minutes later. ${ }^{2}$ Other observations were made in which the hæmorrhage was preceded by the intravenous infusion of a blood volume of normal Ringer's solution. When this had been disposed of, the animals were bled and stood the operation well. The method is, however, evidently not very sound, and the matter was not pursued. The results, such as they are, are shown in Table XIII. and Fig. 7. The data were obtained in the usual way, the actual hæmorrhage taking, as near as could be adjusted, one and a half minutes. As is well known, a certain amount of liquid passes from the tissues to the blood during the course of the hæmorrhage: a good deal comes out during the next few minutes, and thereafter the restoration of the blood volume progresses much more slowly. The experiments detailed show no definite difference between normal and nephritic animals, and give no support to the hypothesis of a

${ }^{1}$ Which, as far as our observations go (Boycott and Ryffel, this Journal, 1913, vol. xvii. p. 480), does not occur.

${ }^{2}$ Such hæmorrhages are, of course, well borne by unanæsthetised rabbits with a slower rate of loss (from the ear veins instead of the carotid). The present animals died unexpectedly without premonitory symptoms, and apparently directly from cardiac failure. 


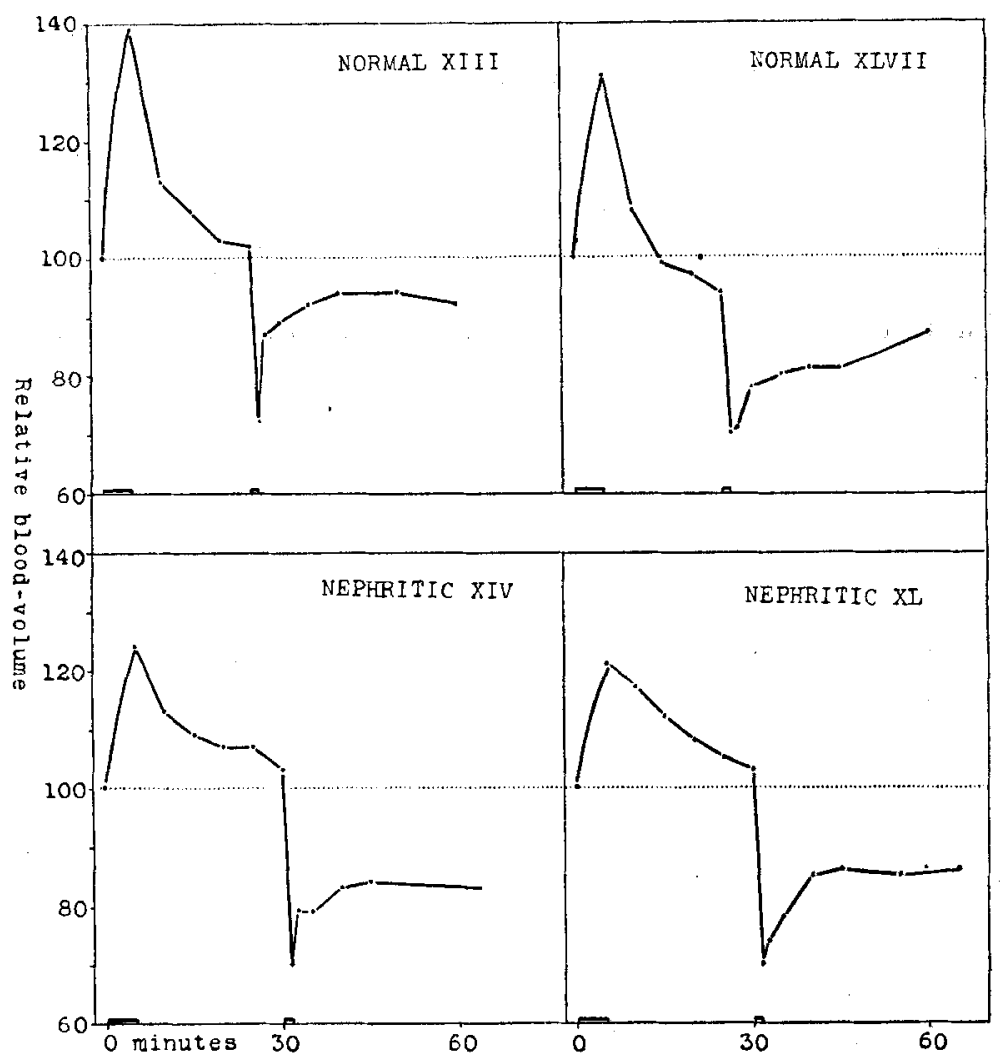

FIG. 7.

TABLE XIII.-Injection of Ringer's Solution followed by Hamorrhage.

\begin{tabular}{|c|c|c|c|c|c|c|c|c|c|c|c|}
\hline \multirow{3}{*}{ No. } & \multirow{3}{*}{$\begin{array}{l}\text { Sex and } \\
\text { Weight. }\end{array}$} & \multirow{3}{*}{ 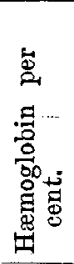 } & \multirow{3}{*}{ 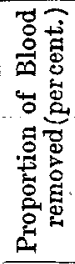 } & \multirow{3}{*}{ 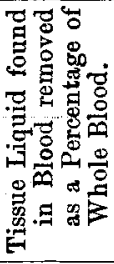 } & \multicolumn{7}{|c|}{ Relative Blood Volume after } \\
\hline & & & & & \multicolumn{7}{|c|}{ Minutes. } \\
\hline & & & & & $2 \frac{1}{2}$ & 5 & 10 & 15 & 20 & 25 & 35 \\
\hline \multicolumn{12}{|c|}{ Normal Animals - } \\
\hline xIII. & F., 2250 & 73 & 31 & $2 \cdot 7$ & 87 & 89 & 92 & 94 & 94 & 94 & 92 \\
\hline XLVII. & F., 1920 & 75 & 30 & $1 \cdot 7$ & 71 & 78 & 80 & 81 & 81 & ... & 87 \\
\hline \multicolumn{12}{|c|}{ Nephritic Animals - } \\
\hline xiv. & F., 2050 & 62 & 36 & $5 \cdot 6$ & 79 & 79 & 83 & 84 & $\ldots$ & ... & 83 \\
\hline $\mathrm{XL}$. & M., 2000 & $80 \cdot 5$ & 32 & $1 \cdot 8$ & 74 & 78 & 85 & 86 & $\cdots$ & 85 & 86 \\
\hline
\end{tabular}


decreased permeability in the latter. They also show, however, that, if the permeability is normal or thereabouts, there is no accumulation of tissue liquid in the nephritic animals. This corresponds with what has already been said with regard to alterations in body weight and anatomical evidences of cedema in them.

It will have been noticed that the differences between the normal and nephritic animals are most marked in the periods following the completion of the injection. Indeed, during the first five minutes there is

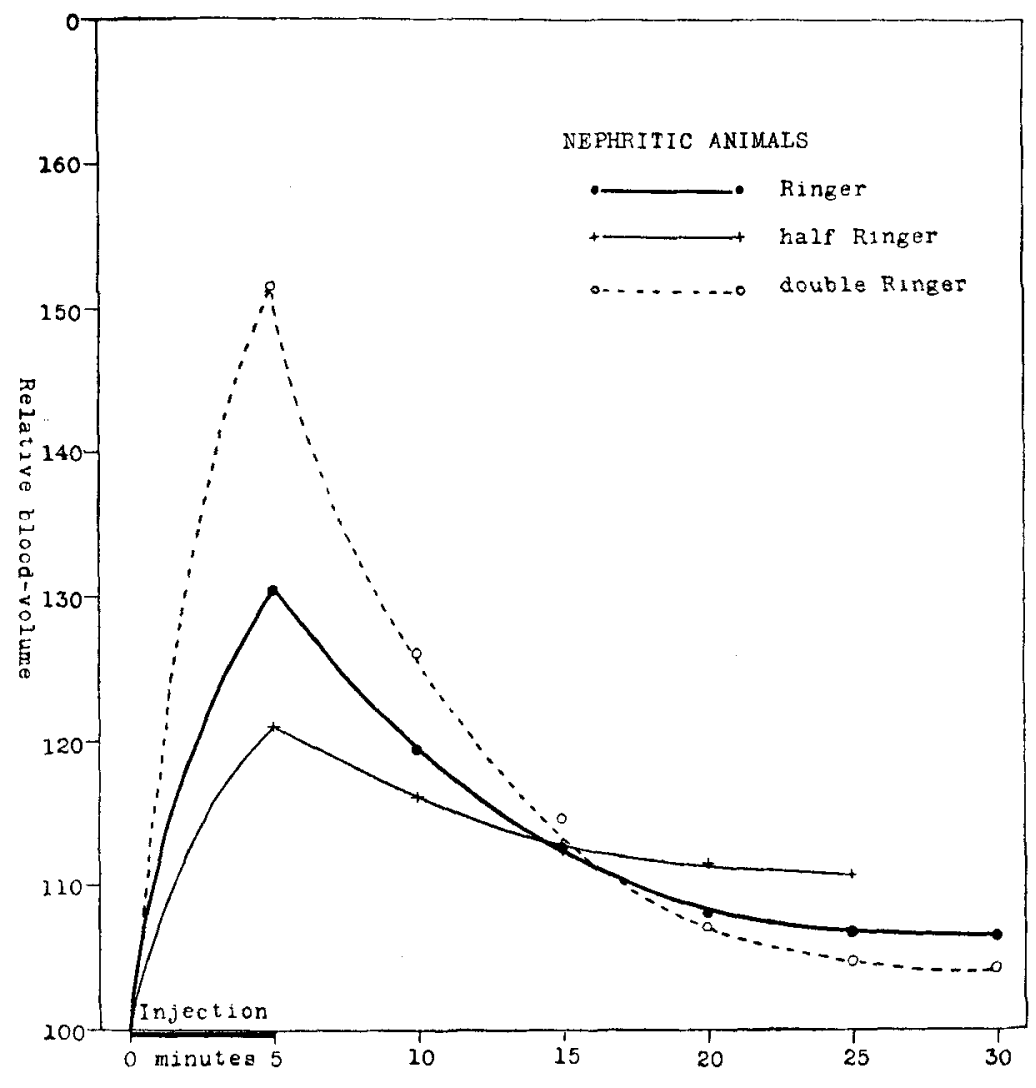

Fig. 8.

no appreciable difference, except in the experiments with Ringer of double strength. This suggests that the diminished permeability in nephritic animals is most obvious when the stimulus towards readjustment of the blood volume is not too great, and that it might be better brought out with slower rates of injection. At the same time, it has to be recognised that the kind of stimulus may be varying as well as the degree during the progressive diminution of blood volume, and that the permeability to one sort of stimulus may be different from that to another. These are points which cannot be elucidated without a further analysis of the changes in composition of the blood. 
In the present series this has not been done, since the main facts of the process would have been interfered with by the rather large samples of blood required. Information of this kind is also wanted to explain why the differences between normal, weak, and strong Ringer's solutions, which are quite definite in normal animals, become obliterated to a considerable extent in nephritic rabbits (see Fig. 8). At present I have only examined serum taken at the end of the experiments after two or three injections of salt solution for the content in chlorides. ${ }^{1}$ Normal rabbit's serum has 0.60 to 0.65 per cent. $\mathrm{NaCl}$ without much variation; after normal Ringer's solution $(0.9$ per cent. $\mathrm{NaCl})$ this figure rises to 0.7 or nearly 0.8 , after dilute Ringer $(0.45$ per cent.) it falls to about 0.55 , and after strong Ringer ( 1.8 per cent.), it rises to about 0.85 per cent. $\mathrm{NaCl}$. There is no obvious difference between normal and nephritic animals. These figures, be it noted, are derived from samples of serum taken when the blood volume had more or less completely returned to the normal level, or when the blood volume had ceased to change any further. They indicate, therefore, that with the normal and strong solutions proportionately more water than salt leaves the vessels, and with the dilute solution rather more salt than water. Whether or not they also show the point at which blood serum and tissue juice come into equilibrium is, however, another matter; the point is one of importance, since its solution would enable us to ascertain the quantity of tissue juice.

1 The analyses were done either after gentle ignition of the serum or, which is more convenient, boiling with nitric acid and excess of silver nitrate; the figures represent, therefore, the total, not necessarily the effective, chlorides. 